\title{
Cure characteristics, swelling behaviour and tensile properties of carbon black-filled Natural Rubber (NR)/Chloroprene Rubber (CR) blends in the presence of alkanolamide
}

\author{
Indra Surya ${ }^{1,2^{*}}$, Mimpin Ginting ${ }^{3}$, and Hanafi Ismail $^{4}$ \\ ${ }^{1}$ Universitas Sumatera Utara, Department of Chemical Engineering, Medan, Indonesia \\ ${ }^{2}$ Universitas Sumatera Utara, Sustainable Energy and Biomaterial Center of Excellence, Faculty of Engineering, Medan, Indonesia \\ ${ }^{3}$ Universitas Sumatera Utara, Department of Science of Chemistry, Medan, Indonesia \\ ${ }^{4}$ Universiti Sains Malaysia, School of Materials and Mineral Resources Engineering, Penang, Malaysia
}

\begin{abstract}
The cure characteristics, swelling behaviour and tensile properties of carbon black (CB)-filled natural rubber (NR)/chloroprene rubber (CR) blends in the presence of alkanolamide (ALK) were investigated. The NR/CR blends were prepared at 50/50 blend ratio. The ALK was prepared from Refined Bleached Deodorized Palm Stearin (RBDPS) and diethanolamine and added into the CB-filled NR/CR blends as a rubber additive. The ALK loadings were 0.0, 1.0, 3.0, 5.0 and $7.0 \mathrm{phr}$. It was found that the ALK exhibited shorter scorch and cure times and higher elongation at break of the CB-filled NR/CR blends. The ALK also exhibited higher torque differences, tensile modulus and tensile strength up to $5.0 \mathrm{phr}$ of ALK and then decreased with further increases in the ALK loading. The swelling test proved that the 5.0 phr loading of ALK caused the highest degree in crosslink density of the CB-filled NR/CR blends.
\end{abstract}

\section{Introduction}

The blending of rubber is a mixing operation that blends two or more types of base rubber with a number of rubber additives. Each part of rubber blends has a specific function either in processing, curing or end use of the rubber products. The blended rubbers will provide rubbery behavior to the products; rubber additives such as plasticisers decrease viscosity, improve deformability and alter properties; curing agents cross-link the rubber chains; and accelerators enhance the performance of curing agents to speed up the resultant crosslinking formation [1].

The rubber additives are classified into curative and noncurative additives. Curative additives affect the rate and nature of the curing process. Magnesium and zinc oxides $(\mathrm{MgO}$ and $\mathrm{ZnO})$ together with ethylene thiourea (ETU) are widely utilised as curative additives for Polychloroprene Rubber (CR) [2-3]. Both of the metal oxides are utilised as curing agents and ETU as the curing accelerator. ETU is a toxic material and is suspected to be carcinogenic [4-5] and hence, an appearance of an alternative curing accelerator for CR has been in demand.

Fillers are considered as noncurative additives. The main purpose of utilising them is to improve the mechanical properties of rubber vulcanisates such as tensile strength, resistance to abrasion, tearing and flexing or cheapen the cost of products [1].

Generally, in the manufacturing of various rubber products, silica or carbon black (CB) is used to reinforce the rubber compounds. However, at a relatively higher filler loading, their filler particles tend to agglomerate and it will deteriorate the properties of the rubber products. Practically, to solve the filler dispersion problem, special additives such as processing aid, dispersant aid, etc. are used.

Based on the above reasons, ALK is likely to yield some good results in replacing the carcinogenic ETU as a curing agent [6] and also solving the problem of filler dispersion. Therefore, this study reports the application of ALK as a curative additive for CB-filled NR/CR blends. The effects of ALK on cure characteristics, swelling behaviour and tensile properties of CB-filled NR/ CR blends were reported.

\section{Experimental}

\subsection{Materials}

NR grade SMR L was used and obtained from Guthrie (M) Sdn. Bhd., Seremban, Malaysia. The N-220 grade of CB was supplied by Cabot Corporation. Polychloroprene rubber (CR) (Skyprene B-30) was purchased from TOSOH Co. (Japan). Other compounding ingredients such as sulphur, zinc oxide, magnesium oxide, stearic acid,N-isopropyl-N'-phenyl-p-phenylenediamine (IPPD), $\mathrm{N}$-cyclohexyl-benzothiazylsulfenamide (CBS) and Tetra-methylthiuram disulfide (TMTD) were supplied by Bayer (M) Ltd., Sdn. Bhd., Petaling Jaya, Selangor, Malaysia. All materials were used as supplied. The ALK

\footnotetext{
Corresponding author: indradanas@yahoo.com
} 
was prepared in the laboratory using Refined Bleached Deodorized Palm Stearin (RBDPS) and diethanolamine [7]. The chemical formula of ALK is, $\mathrm{CH}_{3}\left(\mathrm{CH}_{2}\right)_{14} \mathrm{CON}$ $\left(\mathrm{CH}_{2} \mathrm{CH}_{2} \mathrm{OH}\right)_{2}$.

\subsection{Compounding}

A semi-efficient vulcanization system was used for the rubber blending. The recipe for the preparation of the $\mathrm{NR} / \mathrm{CR}$ blend is given in Table 1. The blending procedure was done in accordance with the American Society for Testing and Material (ASTM) - Designation D $3184-80$.

The blending was done on a two-roll mill. Table 2 shows the designation and composition of the NR/CR blends used in this study.

Table 1. The composition of CB-filled NR/CR blends without/with ALK.

\begin{tabular}{|c|c|}
\hline Ingredients & Content, phr* $^{*}$ \\
\hline $\mathrm{NR} / \mathrm{CR}$ & $50 / 50$ \\
\hline $\mathrm{ZnO}$ & 5.0 \\
\hline $\mathrm{MgO}$ & 4.0 \\
\hline Stearic acid & 1.0 \\
\hline IPPD & 1.0 \\
\hline CBS & 1.0 \\
\hline TMTD & 0.5 \\
\hline ETU & 0.5 \\
\hline Sulphur & 2.0 \\
\hline CB N-330 & 30.0 \\
\hline ALK & $0.0 ; 1.0 ; 3.0 ; 5.0 ; 7.0$ \\
\hline
\end{tabular}

Table 2. The designation and composition of the CB-filled NR/CR blends without and with ALK.

\begin{tabular}{|l|l|}
\hline \multicolumn{1}{|c|}{ Designation } & \multicolumn{1}{|c|}{ Composition } \\
\hline $\begin{array}{l}\text { NR/CR-0.0 } \\
\text { (Control blend) }\end{array}$ & CB-filled NR/CR blend without ALK \\
\hline NR/CR-1.0 & $\begin{array}{l}\text { CB-filled NR/CR blend with ALK } \\
(1.0 \text { phr })\end{array}$ \\
\hline NR/CR-3.0 & $\begin{array}{l}\text { CB-filled NR/CR blend with ALK } \\
\text { (3.0 phr) }\end{array}$ \\
\hline NR/CR-5.0 & $\begin{array}{l}\text { CB-filled NR/CR blend with ALK } \\
\text { (5.0 phr) }\end{array}$ \\
\hline NR/CR-7.0 & $\begin{array}{l}\text { CB-filled NR/CR blend with ALK } \\
\text { (7.0 phr) }\end{array}$ \\
\hline
\end{tabular}

\subsection{Cure characteristics}

The cure characteristics of the rubber blends were obtained using a Monsanto Moving Die Rheometer (MDR 2000) which was employed to determine the scorch time $\left(\mathrm{ts}_{2}\right)$, cure time $\left(\mathrm{t}_{90}\right)$ and torque difference $\left(\mathrm{M}_{\mathrm{H}}-\mathrm{M}_{\mathrm{L}}\right)$ value according to ISO 3417. Samples of the respective rubber blends were tested at $150{ }^{\circ} \mathrm{C}$. The rubber blends were subsequently compression moulded using a stainless steel mould at $150{ }^{\circ} \mathrm{C}$, with a pressure of $10 \mathrm{MPa}$ and applying a laboratory hot-press based on respective curing times.

\subsection{Swelling behaviour}

Swelling behaviours were performed in toluene in accordance with ISO 1817 . Cured test pieces (30 mmx5 $\mathrm{mmx} 2 \mathrm{~mm}$ ) were weighed using an electrical balance and swollen in toluene until equilibrium, which took 72 $\mathrm{h}$ at room temperature. The samples were removed from the liquid, the toluene was removed from the sample surfaces, and the weight was determined. The change in mass is as follows:

$$
\text { Swelling }(\%)=100 \%\left(\mathrm{~W}_{2}-\mathrm{W}_{1}\right) / \mathrm{W}_{1}
$$

Where $\mathrm{W}_{1}$ is the initial mass $(\mathrm{g})$ and $\mathrm{W}_{2}$ is the mass (g) after immersion in toluene.

\subsection{Tensile properties}

Dumbbell-shaped samples were cut from the moulded sheets according to ISO 37 . Tensile tests were performed at a crosshead speed of $500 \mathrm{~mm} / \mathrm{min}$. Tensile tests were carried out with a universal tensile machine Instron 3366 to determine the tensile properties in terms of tensile strength (TS), stresses at 100\% and 300\% elongations (M100, M300) and elongation at break (EB).

\section{Results and discussion}

\subsection{The cure characteristics of the CB-filled NR/CR blends without/with ALK}

The cure characteristics of the CB-filled NR/CR blends without and with ALK are shown in Table 3. Both scorch and cure times of NR/CR-1.0 blend were lower than those of NR/CR-0.0. ALK caused enhancement in the cure. The higher the ALK loading the lower were the scorch and cure times and the more pronounced was the cure enhancement. It was due to the function of ALK as a co-curing (curative) agent. The ALK acted as an additional accelerator and its amine-content improved the degree of curing [7-9].

Table 3. The cure characteristics, tensile properties and swelling percentage of CB-filled NR/CR blends without/with ALK.

\begin{tabular}{|c|c|c|c|c|c|c|c|c|}
\hline \multirow[b]{2}{*}{ Rubber blends } & \multicolumn{3}{|c|}{ Cure characteristics } & \multicolumn{4}{|c|}{ Tensile properties } & \multirow{2}{*}{$\begin{array}{c}\text { Swelling } \\
\text { percentage } \\
(\%)\end{array}$} \\
\hline & $\begin{array}{l}\text { ts } 2, \\
\text { (min.) }\end{array}$ & $\begin{array}{c}\mathrm{t}_{90} \\
\text { (min.) }\end{array}$ & $\begin{array}{c}\mathrm{M}_{\mathrm{H}}-\mathrm{M}_{\mathrm{L}} \\
(\mathrm{dN} . \mathrm{m})\end{array}$ & $\begin{array}{l}\text { M100, } \\
(\mathrm{MPa})\end{array}$ & $\begin{array}{l}\text { M300, } \\
(\mathrm{MPa})\end{array}$ & $\begin{array}{c}\mathrm{TS} \\
(\mathrm{MPa})\end{array}$ & $\begin{array}{l}\text { EB, } \\
(\%)\end{array}$ & \\
\hline NR/CR-0.0 & 1.04 & 3.95 & 14.67 & 2.686 & 10.200 & 18.8 & 527.6 & 1.599 \\
\hline NR/CR-1.0 & 1.01 & 3.87 & 15.57 & 2.855 & 11.500 & 20.0 & 531.7 & 1.557 \\
\hline NR/CR-3.0 & 0.90 & 3.76 & 16.95 & 3.155 & 12.000 & 21.0 & 548.3 & 1.537 \\
\hline NR/CR-5.0 & 0.70 & 3.38 & 18.69 & 3.587 & 13.590 & 22.8 & 558.0 & 1.401 \\
\hline NR/CR-7.0 & 0.67 & 3.37 & 14.63 & 2.576 & 9.9000 & 20.2 & 568.5 & 1.617 \\
\hline
\end{tabular}

Note: $\mathrm{M}_{\mathrm{L}}=$ Minima torque; $\mathrm{M}_{\mathrm{H}}=$ Maxima torque; $\mathrm{M}_{\mathrm{H}}-\mathrm{M}_{\mathrm{L}}=$ Torque difference 
The torque difference $\left(\mathrm{M}_{\mathrm{H}}-\mathrm{M}_{\mathrm{L}}\right)$ of $\mathrm{NR} / \mathrm{CR}-1.0$ was higher than that of NR/CR-0.0. The ALK increased the torque difference value. Further increases in the ALK loading increased the torque difference up to a $5.0 \mathrm{phr}$ of ALK. Beyond the loading, the torque difference decreased. The torque difference represents shear dynamic modulus and it relates to the crosslink density of a rubber vulcanisate [10-13]. The addition of ALK affected the torque difference or the crosslink density of the CB-filled NR/CR blends. It was due to the action of the ALK as an additional accelerator and internal plasticiser [7-9] which enhanced the state of the curing process, improved filler dispersion, respectively.

The reduction of crosslink density beyond $5.0 \mathrm{phr}$ of ALK loading was due to the more pronounced the plasticizing effect of the excessive ALK which dissolved a part of the elemental sulphur [7-9] and hence reduced crosslink density.

\subsection{The swelling behaviour of the CB-filled NR/CR blends without/with ALK}

The swelling percentage of the CB-filled NR/CR blends without/with ALK is shown in Table 3. The swelling percentage was measured by toluene uptake until equilibrium swelling was reached at room temperature. The swelling relates to the crosslink density of a network chain $[13,14]$, with less toluene uptake or penetration into the blends indicating a higher degree of crosslink density. Therefore, the swelling percentage of CB-filled NR/CR blends decreased with the addition of ALK up to $5.0 \mathrm{phr}$, and increased with further increases in the ALK loading. The increases in swelling percentage might be due to the excessive loading of ALK which reduced the degree of crosslink density $[6,8]$.

\subsection{The tensile properties of the CB-filled NR/CR blends without/with ALK}

The tensile properties of the CB-filled NR/CR blends without and with ALK are also shown in Table 3. The addition of $1.0 \mathrm{phr}$ ALK produced an NR/CR-1.0 rubber blend with a higher EB. Increasing the ALK loading caused further increases in the percentage of $\mathrm{EB}$ or the extensibility of the rubber blends. This was due to the function of ALK as an internal plasticiser which modified flexibility or distensibility of rubber blends [7$10]$.

The addition of ALK increased the M100 and M300 up to the maximum level at a $5.0 \mathrm{phr}$ and decreased with further increases in the ALK loading. The results of tensile strength also exhibit the similar trend. Tensile modulus and tensile strength are dependent only on the degree of crosslink [15]. The improvement of those properties was attributed to a higher degree of crosslink (as indicated by a higher value of torque difference). The deterioration of those properties was due to the excessive amount of ALK which dissolved other curative and hence decreased the degree of crosslink density (as indicated by a lower value of torque difference). As discussed earlier, the degree of crosslink density of a rubber compound is indicated by torque difference value. The greater the torque difference, the higher is the degree of crosslink density $[1,10]$.

\section{Conclusions}

From this study, the following conclusions were drawn:

- Alkanolamide acted as a curative additive and plasticiser in carbon black-filled natural rubber/chloroprene rubber blends.

- The scorch and cure times of carbon black-filled natural rubber/chloroprene rubber blends with alkanolamide were lower than those of without alkanolamide.

- The elongations at break of carbon black-filled natural rubber/chloroprene rubber blends with alkanolamide were higher than that of without alkanolamide.

- The tensile properties, torque difference and degree of crosslink density of the carbon black-filled natural rubber/chloroprene rubber blends increased up to $5.0 \mathrm{phr}$ of alkanolamide loading.

The authors would like to thank Universiti Sains Malaysia, for providing the research facilities for carrying out the experiment and for making this research work possible. Indra Surya and Syahrul Fauzi Siregar are grateful to Universitas Sumatera Utara for the Talenta research grant under contract No. 5338/UN5.1.R/PPM/ 2017.

\section{References}

1. I. Surya, SF. Siregar and H. Ismail, IOP Conf. Ser., Mater. Sci. Eng 223, 012012 (2017)

2. M. Akiba and A. Hashim, Prog. Polym. Sci 22, 475 (1997)

3. B. Rodgers, Chemistry and Applications (CRC, 2004)

4. R. Chhabra, S. Eustis, J. Haseman, P. Kurtz and B. Carlton, Fundam. Appl. Toxicol 18, 405 (1992)

5. D.M. Smith, Br J Ind Med 41, 362 (1984)

6. I. Surya and H. Ismail, Plast Rubber and Compos 45, 287 (2016)

7. I. Surya, H. Ismail and A. Azura, Polym Test 32, 1313 (2013)

8. I. Surya, H. Ismail and A. Azura, Polym Test 40, 24 (2014)

9. I. Surya, H. Ismail and A. Azura, Polym Test 42, 208 (2015)

10. I. Surya and H. Ismail, Polym Test 50, 276 (2016)

11. I. Surya, M. Ginting and H. Ismail, IOP Conf. Ser., Mater. Sci. Eng Vol. 223, 012006 (2017)

12. P. Teh, Z. Mohd Ishak, A. Hashim, J. KargerKocsis and U. Ishiaku, Eur. Polym. J 40, 2513 (2004) 
13. H. Ismail and C. Ng, J Elastomers Plast 30, 308 (1998)

14. H. Nabil, H. Ismail and A. Azura, Polym Test 32, 385 (2013)

15. H. Ismail and H. Chia, Polym Test 17, 199 (1998) 